\title{
Disinfectant Spraying Robot to Prevent the Transmission of the Covid-19 Virus Based on the Internet of Things (IoT)
}

\author{
Indah Sulistiyowati*, Moh. Imam Muhyiddin \\ Department of Electrical Engineering, Faculty of Science and Technology, \\ Universitas Muhammadiyah Sidoarjo, East Java, Indonesia \\ *Corresponding author, email: indah_sulistiyowati@umsida.ac.id
}

\begin{abstract}
One way to prevent the transmission and spread of Covid-19 is to always keep ourselves and our environment clean. Maintaining personal and environmental hygiene can be done by using antiseptics and disinfectants. Disinfectants that are not used properly will be bad for humans. That is why so far the spraying of disinfectants for the prevention of COVID-19 has been carried out by human workers who are dressed in complete Personal Protective Equipment $(P P E)$ using manual sprayers. This is certainly very risky to humans who do the spraying manually. The objective of this research is to minimize the risk of spraying disinfectants, by using a robotic power to spray disinfectant based on the Internet of Things (IoT) and a camera. This robot is operated by using a smartphone while to determine the environmental conditions around it is used a camera. From the test results, it obtained data that the robot works well and is quite reliable due to the wider scope limit because it uses an IoT connection to communicate with smartphones. The results of camera readings on laptops are also quite clear, although the higher the resolution on the display, the lag time required to transfer images to the laptop affects.
\end{abstract}

Keywords: Robot, internet of things, camera

\section{Introduction}

Currently, almost all citizens in the world are facing an outbreak of the SARS-CoV-2 coronavirus or the Covid-19 virus, including in Indonesia. At least 220 countries have been exposed to the virus, which first appeared in Wuhan, China (World Health Organization, 2021). With the number of patients who continue to increase until now. [1]

One way to prevent the transmission and spread of Covid-19 is to always keep ourselves and our environment clean. Maintaining personal and environmental hygiene can be done by using antiseptics and disinfectants. Disinfectants are substances that can kill pathogens in the environment and usually contain glutaraldehyde and formaldehyde.[2]

The problem is, disinfectants that are not used properly will be bad for humans.[3] Disinfection is a decontamination process that removes or kills all things related to microorganisms (both viruses and bacteria) on inanimate objects. [4]
Personnel preparing or using disinfectants in health care facilities require special Personal Protective Equipment PPE because of the high concentration of disinfectants used in these facilities and the duration of exposure to the disinfectant during work.[5] Although there is still a chance of risk to humans who do this manual spraying. The use of disinfectant liquid will have an impact if it comes into contact with the skin when spraying. [6]

Therefore, appropriate innovations are needed that can minimize the risk of spraying disinfectants, one of which is by applying the use of robot technology. From these problems, the authors designed a robotic disinfectant to prevent the Covid-19 virus based on the Internet of Things (IoT). It is hoped that this tool can help and better maintain the health of officers in spraying disinfectants.

\section{Material and Methods}

In designing this system, several studies have been carried out before, including research by Syamsuddin RS on the design of a humidifier 
machine as covid-19 prevention protection with lemongrass natural disinfectant liquid. This tool uses a simple humidifier machine using a mist maker as the main component to produce steam that can humidify the air where the disinfectant used comes from natural ingredients of citronella essential oil. A humidifier with a mist maker as the main component can convert the disinfectant solution into steam through an ultrasonic automation process with a frequency of $1.7 \mathrm{MHz}$. [7]

\section{II.1 NodeMCU ESP 8266}

It is an open-source IoT (Internet Of Things) platform. It is a microcontroller circuit board that already has a wifi module in it which functions to connect the microcontroller to a wifi network. Which can also function as a client or server depending on the commands programmed in the microcontroller.[8]

The main component used here is the NodeMCU ESP8266 microcontroller module because it is used as a control center and data traffic. The NodeMCU ESP8266 module will be sourced from a $12 \mathrm{~V}$ battery. Based on the Datasheet of the NodeMCU ESP8266 Microcontroller, the permissible voltage source for the NodeMCU ESP8266 Microcontroller is $3.3 \mathrm{~V}-5 \mathrm{~V}$, therefore the voltage from the battery is lowered by the DC to DC Converter to $5 \mathrm{~V}$ and then lowered again by the DC to DC Converter to $3.3 \mathrm{~V}$ because to communicate with the wireless NodeMCU module ESP8266 requires a voltage of $3.3 \mathrm{~V}$ and ground from the battery.

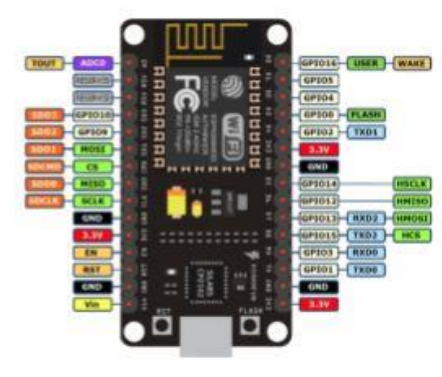

Fig.1. NodeMCU ESP 8266 Pinout

\section{2 Servo $M G 996-R$}

A Servo motor is a device or rotary actuator (motor) designed with a closed-loop feedback control system (servo) so that it can be set up or adjusted to determine and ensure the angular position of the motor output shaft. Servo motor is a DC motor that has an electronic control circuit and internal gear to control the movement and angular angle. Servo motor is a dc motor equipped with gears and a position sensor that can read the rotational position. Generally, servo motors have very good capabilities in terms of very fast position changes, acceleration, and speed. Servo motors are also very reliable in operating in a variable torque range. [9]

A Servo motor will be used to move the robot arm. There are 2 servo motors used. The servo motor is connected to a $5 \mathrm{~V}$ voltage from the DC to DC Converter and ground from the battery. Meanwhile, to regulate the speed and direction of rotation of the DC Motor, the L298N Motor Driver is used, the L298N Motor Driver is connected to a voltage of $12 \mathrm{~V}$ from the battery, 5 $\mathrm{V}$ from the DC to DC Converter, and Ground from the Battery.

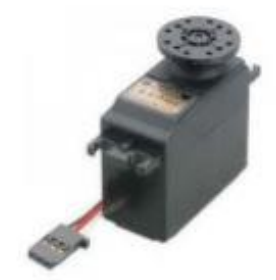

Fig.2. Servo Motor

\section{3 Camera ESP 32}

The ESP 32-CAM is a WiFi/Bluetooth development board with an ESP32 microcontroller and camera. This board does not have a USB to the serial interface. Programming must be done through an external interface. For the programming process Usually use USB to Serial FTDI. Camera ESP 32 operates at 3V: pin RX/TX.[10]

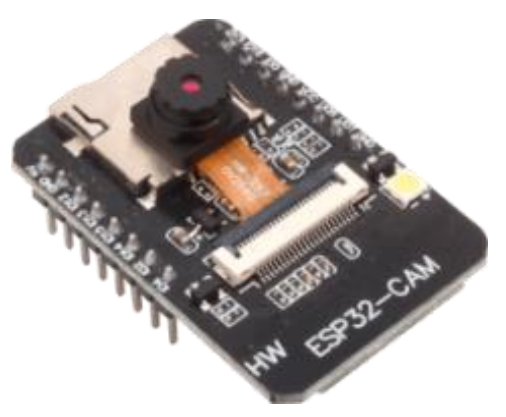

Fig.3. Camera ESP 32 board 


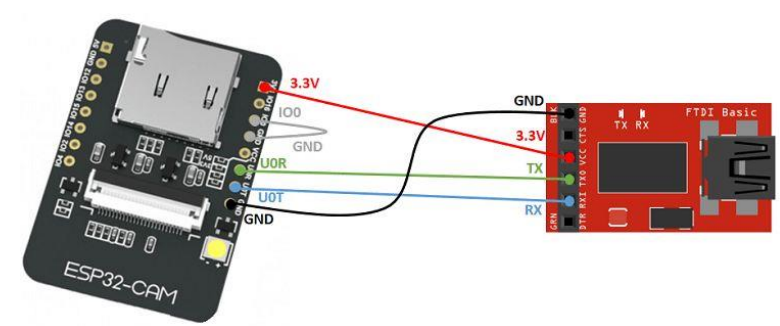

Fig.4. ESP32 Camera Series with USB to serial (FTDI)

TABLE I

Pin AdDRess Placement for ESP 32 CAMERA With USB TO SERIAL (FTDI)

\begin{tabular}{cc}
\hline $\begin{array}{l}\text { ESP Camera Pin } \\
\text { Address } 32\end{array}$ & FTDI Pin Address \\
\hline Vcc & Vcc \\
Gnd & Gnd \\
Our & Tx \\
Out & Rx \\
GPIO_0 & Gnd \\
\hline
\end{tabular}

\section{Result and Discussion}

This robot system is divided into two major blocks, namely Hardware and Software. The hardware section consists of NodeMcu ESP8266, Servo MG996R, L298N Driver, Relay Module, and Camera ESP 32. While the software section consists of a laptop as a camera reading viewer and a smartphone as a robot motion controller. In the picture below is shown a block diagram of the design of the robot.

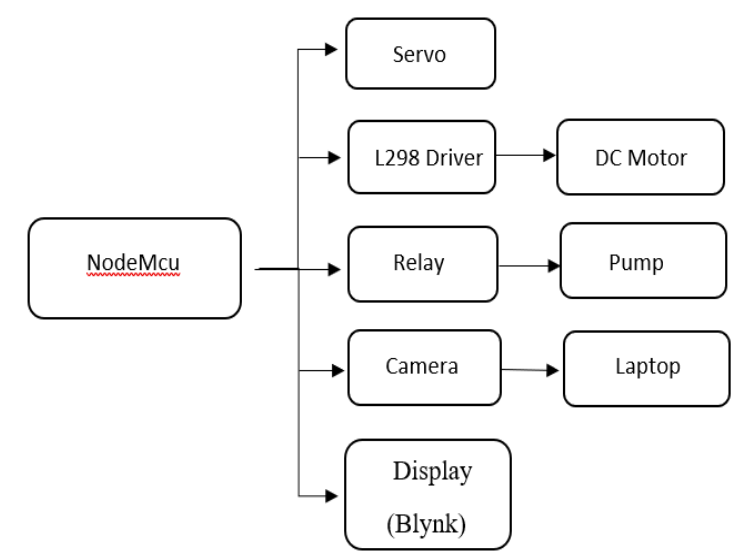

Fig 5. Disinfectant spraying robot block diagram
The main component in this robot is NodeMcu ESP 8266 and as a support, it is used Camera Web server ESP 32 so that later it can be operated remotely via the internet. This robot is equipped with a robotic arm that is driven by a servo motor to spray the surface of objects that are higher than the robot's body. The robot is operated using a smartphone that communicates via the Internet Of Things (IoT), equipped with an ESP 32 CAM to monitor conditions around the robot. The process of spraying disinfectant uses a high-pressure 12 volt DC water pump to produce a misty spray, the robot drives using a 12 volt DC motor.

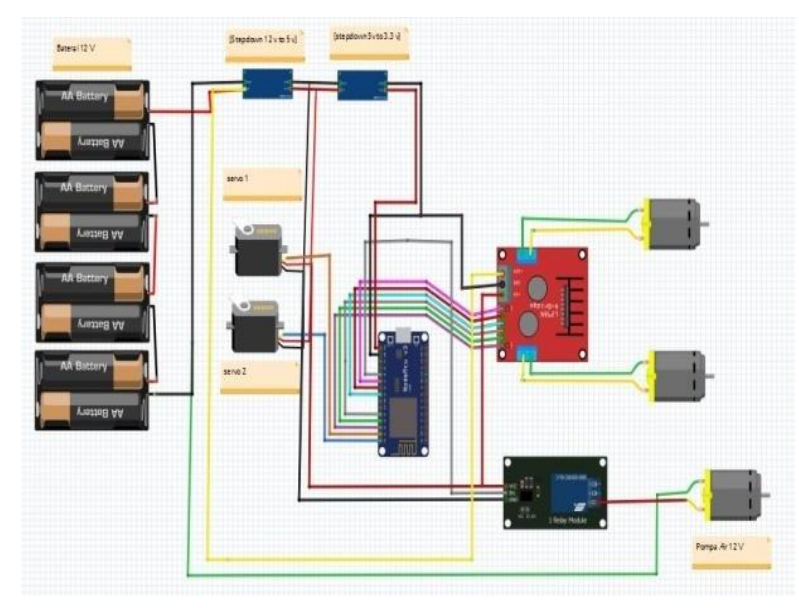

Fig.6. Schematic circuit of the robot

Figure 6 shows the main component used in the manufacture of this robot is the NodeMCU ESP8266 which functions as a control center and data traffic. The NodeMCU ESP8266 module will be sourced from a $12 \mathrm{~V}$ battery. The permissible voltage source for the NodeMCU ESP8266 Microcontroller is $3.3 \mathrm{~V}-5 \mathrm{~V}$, so the voltage from the $12 \mathrm{~V}$ battery is lowered by the DC to DC Converter to $5 \mathrm{~V}$. As a means of wireless communication, the NodeMCU ESP8266 module requires a maximum voltage of $5 \mathrm{~V}$ and a ground from the battery. To operate the water pump, a $5 \mathrm{~V}$ 1 channel relay module is used. The relay module gets $5 \mathrm{~V}$ from the DC to DC Converter and Ground from the battery.

To move the robot arm, 1 metal Gear Servo Motor is used and 112 Volt dc Motor is used, the Servo Motor is connected to a $5 \mathrm{~V}$ voltage from the DC to DC Converter and ground from the battery. Meanwhile, to adjust the speed and direction of rotation of the DC Motor, the L298N Motor Driver is used. The L298N Motor Driver is connected to a voltage of $12 \mathrm{~V}$ from the battery, 5 $\mathrm{V}$ from the DC to DC Converter, and Ground 
from the Battery. This disinfectant spraying robot uses $2 \mathrm{DC} 12 \mathrm{~V}$ motors. The DC motor is connected to Output 1 and Output 2 of the L298N Motor Driver.

This robot uses a Lithium-Ion battery with a capacity of 36 Volt $10 \mathrm{aH}$ as the main source, it is hoped that with the use of this battery the robot can be used for a long period. This battery can be recharged with the help of the charger module. NodeMCU ESP8266 is capable of sending data to the Blynk web server via WiFi. Here's what Blynk looks like:

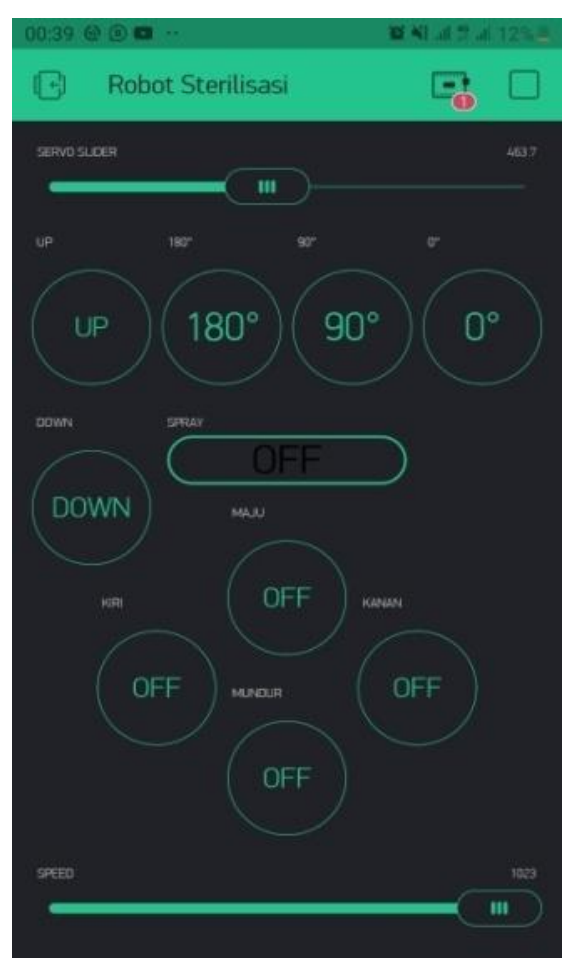

Fig.7. Display on the Blynk app

On the display, there are several widgets to set the direction of movement of the robot. Among them is the "Servo Slider" widget used to move the servo in the desired direction. Widget "180" is used to move the robot arm to the right. The "90" widget is used to move the robot arm forward. Widget " 0 " is used to move the robot arm to the left. The "UP" and "DOWN" widgets are used to move the robot arm up and down. The "Spray" widget is used to turn the water pump on and off. The widgets "Forward", "Backward", "RIGHT", "LEFT" are used to move the robot in the desired direction. While the "SPEED" widget is used to adjust the speed of the robot's movement.

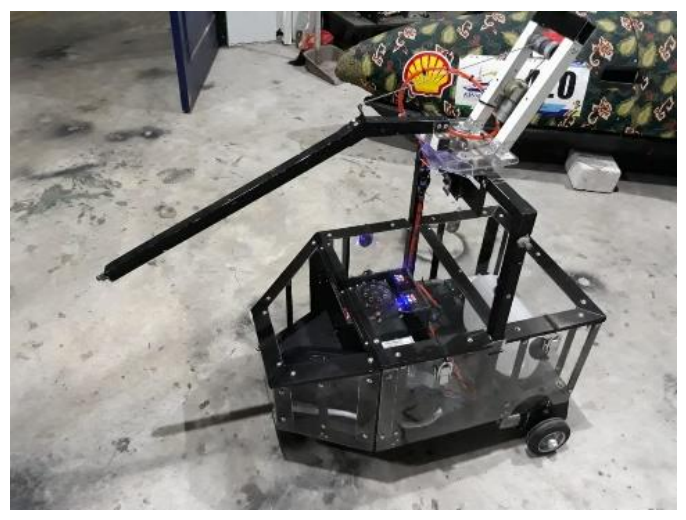

Fig.8. Real robot form

Figure 8 shows the physical form of the disinfectant spraying robot that has been made. There are a series of component boxes, tanks, water pumps, and robotic arms. The robot measures $40 \mathrm{~cm} \times 60 \mathrm{~cm}$ x $70 \mathrm{~cm}$.

To find out whether the robot can do its job as expected, several tests are carried out. Among them is testing Camera 32 to find out whether the room to be sprayed by the robot is what we want and is visible on the camera screen that is connected to the laptop. To test the distance and type of smartphone, 3 types of smartphones are also carried out along with variations in the distance between the device and different smartphones. This is done to get internet of things communication capabilities and compatible applications that have been made for various types of smartphones. In addition, testing of all tools related to the robot was also carried out.

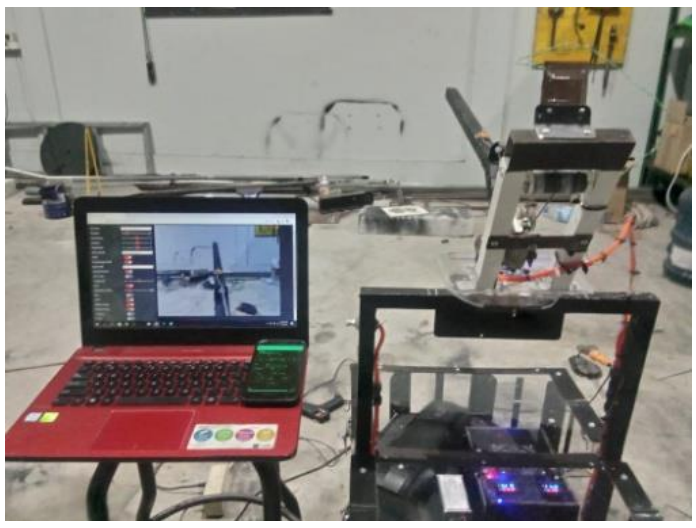

Fig.9. The result of the camera reading on the robot

The test is carried out by connecting the ESP 32 camera that has been installed on the robot with a laptop device as a medium to see the results of camera readings. 
In this overall test, it was concluded that the overall system of the robot can run well even though the Smartphone as the controller is at a very far distance, using Internet Of Things (IoT) technology. The Disinfectant Spraying Robot can be controlled anywhere as long as the robot is connected to a wifi network. The results of camera readings are the same, as long as the Camera Esp 32 module is connected to a Wifi network, the results of camera readings can be accessed from anywhere.

TABLE II

ToOl Testing With the InTERnet of Things-BASEd ANDRoid SMARTPHONE

\begin{tabular}{|c|c|c|c|c|c|c|c|c|c|c|}
\hline \multirow[t]{2}{*}{ No. } & \multirow{2}{*}{$\begin{array}{c}\text { Type of } \\
\text { Smartphone }\end{array}$} & \multirow{2}{*}{$\begin{array}{l}\text { Range } \\
(\mathrm{Km})\end{array}$} & \multicolumn{5}{|c|}{ Trial } & \multirow[b]{2}{*}{ Average } & \multirow[b]{2}{*}{$\begin{array}{l}\text { Standard } \\
\text { Deviation }\end{array}$} & \multirow[t]{2}{*}{ Place Description } \\
\hline & & & 1 & 2 & 3 & 4 & 5 & & & \\
\hline \multirow[t]{3}{*}{1.} & $\begin{array}{l}\text { Samsung J7 } \\
\text { Pro }\end{array}$ & 7.6 & 1 & 1 & 1 & 1 & 1 & 1 & 0 & $\begin{array}{l}\text { From Muhammadiyah Campus } 2 \\
\text { to home }\end{array}$ \\
\hline & $\begin{array}{l}\text { Memori } \\
\text { Internal }\end{array}$ & 22 & 1 & 1 & 1 & 1 & 1 & 1 & 0 & $\begin{array}{l}\text { From Muhammadiyah Campus } 2 \\
\text { to Pandaan }\end{array}$ \\
\hline & $\begin{array}{l}32 \mathrm{~Gb}, \mathrm{RAM} 3 \\
\text { GB,OS } \\
\text { Android } \\
\text { Versi 6.0.1 } \\
\text { (Marshmallow } \\
\text { ) } \\
\text { CPU = Octa- } \\
\text { core 1.6 GHz } \\
\text { Cortex-A53 } \\
\text {, Wi-Fi Direct, } \\
\text { hotspot }\end{array}$ & 67 & 1 & 1 & 1 & 1 & 1 & 1 & 0 & $\begin{array}{c}\text { From Muhammadiyah Campus } 2 \\
\text { to Malang }\end{array}$ \\
\hline 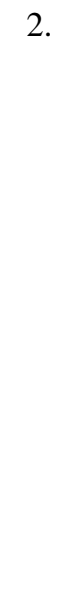 & $\begin{array}{l}\text { Samsung S4 } \\
\text { Memeri } \\
\text { Internal } \\
64 \text { Gb, RAM } 2 \\
\text { Gb, OS } \\
\text { Android } \\
\text { Versi } 8.0 \\
\text { (Exynos } 5 \\
\text { Octa } \\
\text { 5410), CPU = } \\
\text { Quad-core 1,6 } \\
\text { GHz, Wi-Fi } \\
802.11 \text { a/b/g/n, } \\
\text { dual-band, } \\
\text { hotspot }\end{array}$ & 69 & 1 & 1 & 1 & 1 & 1 & 1 & 0 & $\begin{array}{c}\text { From Muhammadiyah Campus } 2 \\
\text { to Pusdik Arhanud } \\
\text { Batu City }\end{array}$ \\
\hline 3. & $\begin{array}{l}\text { Oppo A83, } \\
\text { Memori } \\
\text { Internal } \\
\text { 32GB, RAM = } \\
\text { 3GB, OS } \\
\text { Android versi } \\
\text { v7.1 (Nougat), } \\
\text { CPU = } \\
\text { Octacore } \\
\text { CortexA53, } \\
\text { Wi-Fi } \\
802.11\end{array}$ & 774 & 1 & 1 & 1 & 1 & 1 & 1 & 0 & $\begin{array}{l}\text { From Muhammadiyah Campus } 2 \text { to } \\
\text { Jakarta }\end{array}$ \\
\hline
\end{tabular}


TABLE III

Overall TEST RESUlTS

\begin{tabular}{|c|c|c|c|c|c|c|c|c|c|c|}
\hline \multirow{2}{*}{ No } & \multirow{2}{*}{$\begin{array}{l}\text { Robotic } \\
\text { Condition }\end{array}$} & \multirow{2}{*}{ Range(Km) } & \multicolumn{2}{|c|}{ DC Motor } & \multicolumn{2}{|c|}{ Camera Esp 32} & \multicolumn{2}{|c|}{ Servo } & \multicolumn{2}{|c|}{ Pump } \\
\hline & & & Move & No & Legible & No & Move & $N_{0}$ & Spray & $\mathrm{N}_{0}$ \\
\hline 1. & Connected & $7,6 \mathrm{Km}$ & $\checkmark$ & . & $\checkmark$ & . & $\checkmark$ & . & $\checkmark$ & - \\
\hline 2. & Connected & $22 \mathrm{Km}$ & $\checkmark$ & - & $\checkmark$ & - & $\checkmark$ & - & $\checkmark$ & - \\
\hline 3. & Connected & $67 \mathrm{Km}$ & $\checkmark$ & - & $\checkmark$ & . & $\checkmark$ & . & $\checkmark$ & . \\
\hline 4. & Comnected & $69 \mathrm{Km}$ & $\checkmark$ & . & $\checkmark$ & . & $\checkmark$ & . & $\checkmark$ & . \\
\hline 5. & Connected & $774 \mathrm{Km}$ & $\checkmark$ & - & $\checkmark$ & . & $\checkmark$ & . & $\begin{array}{l} \\
\end{array}$ & . \\
\hline
\end{tabular}

The results of the internet of things-based android smartphone test show that the developed application was successfully used on 3 different types of smartphones, and internet communication between the measuring instrument and the smartphone was also successfully read and displayed.

Regarding the analysis of network types such as the type of network that exists on the Samsung Galaxy S4 and Oppo A83 android smartphones which have an internet connection with a $4 \mathrm{G}$ network, it shows that the delivery is going well because the speed of the $4 \mathrm{G}$ internet connection is faster. Using the $4 \mathrm{G}$ network can make the network more stable so that measurement monitoring is more timely. By using a good internet network as a liaison in device communication with smartphones, it greatly affects communication and data transmission between devices and smartphones. The furthest test was carried out at a distance of $774 \mathrm{~km}$ (Sidoarjo and Jakarta), the test results ran smoothly and the measurement data were successfully displayed.

\section{Conclusion}

After analyzing the testing and data collection, it can be concluded that:

The results of the camera reading on the laptop are quite clear, but with the higher resolution on the selected display, the lag time required to transfer images to the laptop affects.

The results of the internet of things-based android smartphone test show that the developed application was successfully used on 3 different types of smartphones, and internet communication between the measuring instrument and the smartphone was also successfully read and displayed up to a maximum distance of $774 \mathrm{~km}$ (Sidoarjo-Jakarta). The results of this test are very good for supporting the safety of officers in spraying disinfectants to prevent the covid-19 virus in minimizing the risks that arise when spraying disinfectants.

\section{Acknowledgements}

Thank you to the PP Muhammadiyah Higher Education Research and Development Council (Diklitbang) for funding the research to produce this article (RISETMU). The author would also like to thank several parties who have assisted in completing the research and writing this article.

\section{References}

[1] COVID-19 Coronavirus 2019-nCov Statistics Update (Live), “191.733.410 Cases and 4, 133, 054172 Deaths.," Available online. https://virusncov.com/.

[2] Lacapelle, "antiseptic and disinfectan," Kanerva's Occup. Dermatology. Springer, Cham., 2020, doi: https://doi.org/10.1007/9783-319-68617-2_36.

[3] A. L. Larasati, D. Gozali, and C. Haribowo, "Penggunaan Desinfektan dan Antiseptik Pada Pencegahan Penularan Covid-19 di Masyarakat," Maj. Farmasetika, vol. 5, no. 3, pp. 137-145, 2020, doi: 10.24198/mfarmasetika.v5i3.27066.

[4] A. Athena, E. Laelasari, and T. Puspita, "Pelaksanaan Disinfeksi Dalam Pencegahan Penularan Covid-19 Dan Potensi Risiko Terhadap Kesehatan Di Indonesia," J. Ekol. Kesehat., vol. 19, no. 1, pp. 1-20, 2020, doi: 10.22435/jek.v19i1.3146.

[5] World Health Organization, "Pembersihan dan disinfeksi permukaan lingkungan dalam konteks COVID-19," Pandu. interim, pp. 1-9, 2020, [Online]. Available: who.int.

[6] Y. K. Zulkifri, Ahmad; Ashar, "Dampak Cairan Disinfektan Terhadap Kulit Tim Penyemprot Gugus Tugas Covid-19 Kota Binjai," J. Menara Med., vol. 3, no. 1, pp. 714, 2020, [Online]. Available: https://eresources.perpusnas.go.id:2125/media/publicati ons/326196-hubungan-pengetahuan-tentangkesehatan-r-0e91516f.pdf.

[7] R. Syamsuddin, A. A. Latief, and A. M. Ridwan, "Rancang Bangun Mesin Humidifier sebagai Proteksi Pencegahan Covid-19 dengan Cairan Desinfektan Alami Sereh Wangi," Fak. Dakwah dan Ilmu Komun. Bandung, vol. 1, no. 2, pp. 11-19, 2020, [Online]. Available: http://digilib.uinsgd.ac.id/30702/. 
[8] I. Sulistiyowati, A. R. Sugiarto, and J. Jamaaluddin, "Smart Laboratory Based on Internet of Things in the Faculty of Electrical Engineering, University of Muhammadiyah Sidoarjo," IOP Conf. Ser. Mater. Sci. Eng., vol. 874 , no. 1, 2020, doi: 10.1088/1757899X/874/1/012007.

[9] U. Latifa and J. S. Saputro, "Perancangan Robot Arm Gripper Berbasis Arduino Uno," Barometer, vol. 3, no. 2, pp. 138-141, 2018.

[10] AI-Thinker, "ESP32-Cam Module," AIThinker Technol., pp. 1-4, 2017.

\section{Authors' information}
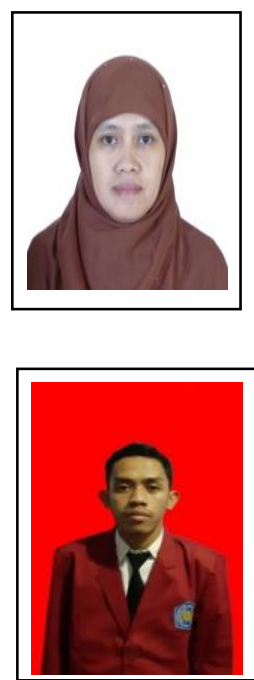

twice.
Indah Sulistiyowati is a lecturer at the Department of Electrical Engineering, Faculty of Science and Technology, Universitas Muhammadiyah Sidoarjo. She received the M. Eng degree in Electrical Engineering from Institut Teknologi Sepuluh November Surabaya, Indonesia.

Moh Imam Muhyiddin is a graduate of Strate 1 Electrical Engineering Study Program, Faculty of Science and Technology, Universitas Muhammadiyah Sidoarjo. He is the leader of the electric car team at UMSIDA (IMEI Team). His team won second place in the Indonesia energiefficient car competition (KMHE) 